\title{
PROBLEMS OF EPIDEMIOLOGICAL SURVEILLANCE OF WEST NILE FEVER IN UKRAINE
}

\author{
Iryna Demchyshyna*, Yuryi Novohatniy and Igor Nebogatkin \\ Ukrainian Center for Diseases Control and Monitoring of the Ministry of Health of Ukraine, Kyiv, Ukraine
}

\section{Objective}

To define the problems of epidemiological surveillance of West Nile fever (WNF) in Ukraine.

\section{Introduction}

Flaviviridae are one of the most widespread arboviruses in Ukraine. Mosquitoes are vectors of WNF in a majority of cases due to bites during swimming, fishing, work in suburban areas and outdoor recreation without use of individual protection from mosquitoes.

A study of the species composition of bloodsucking mosquitoes is conducted in Ukraine. Existence of natural foci of WNF viruses has been well-proven all over the territory of Ukraine by testing $\mathrm{IgG}$ antibodies in different groups of population, including children [1]. Also, infection of mosquitoes (RNA found in Culex pipiens (including Culex pipiens $f$. molestus, Culiseta annulata)) was registered. Infection of $I$. ricinus and $D$. reticulates was also determined, and it acts as a factor for circulation of virus in the wild too [2].

\section{Methods}

Statistical, serological and epidemiological methods were used during the study. Serological tests included reactions with $\operatorname{IgM}$ and IgG antibody in human serum performed using immunofluorescent and ELISA methods.

\section{Results}

In Ukraine, the causative agent of WNF is detected in all landscapes. It is the main arboviral infection in the forest-steppe zone (53.1\% among all arboviral infections). Enzootic territories are located in 18 regions, 47 administrative districts, and 63 settlements.

The majority of natural foci of WNF is located in the Dnieper leftbank steppes, and also in North-Western and Western forest-steppes. The enzootic territories are located on the East of steppe zone and on the East of forest-steppes. The smallest number of natural foci is registered in the Dnieper right-bank part of the steppes. Enzootic territories are absent in Chernivtsi, Chernihiv, Sumy, Ternopil, Luhansk, Kirovohrad Oblasts and Kyiv. Most of them are located in Zaporizhzhia with 9 administrative districts and 16 settlements; in Rivno Oblast - 7 and 9; in Kherson - 5 and 4, and in Poltava Oblasts -2 and 4 respectively [3].

During the period from 2007 to 2016, 86 cases of WNF were registered. WNF was registered in 7 oblasts (Zaporizhzhya - 40 cases, Poltava - 24, Donetsk - 16, Mykolaiv- 3, Kherson, Kharkiv, Zhytomyr Oblasts - one case in each) [4].

Registration of WNF cases separately from other viral hemorrhagic fevers has been conducted in the country since 2010 (official registration of total amount of viral hemorrhagic fevers has been performed since 2005).

In enzootic territories, 2 cases of the diseases were registered and were associated with ticks bites. The strains of WNV were detected in bloodsucking mosquitoes in Rivne and Zaporizhzhia Oblasts and in tick samples of Ixodes genus collected in Lviv Oblast (probably may be found in other species of tick (Argasidae and Gamazoidea) where the causative agent is kept in natural foci under unfavorable conditions)
Laboratory diagnostics was conducted (mainly retrospectively) in Zaporizhzhia, Poltava, Donetsk Oblastss. All diagnoses (exception Mykolaiv Oblast in 2011, data is absent) were laboratory confirmed, including 10 cases confirmed in the State Institution Lviv Research Institute of Epidemiology and Hygiene of the Ministry of Health of Ukraine, and 3 more cases were confirmed by a private laboratory [2].

In total, 129 samples of blood sera collected from patients with clinical manifestations of a fever of unknown origin were delivered to the Laboratory of Virology of Ukrainian Center for Diseases Control and Monitoring during 2016-2017. Samples were investigated using the immunofluorescent and enzyme immunoassay methods including immunoblot. West Nile virus markers such as $\operatorname{IgM} / \operatorname{IgG}$ antibodies have been detected in 4 cases (Poltava oblast) [4].

\section{Conclusions}

Mainly, single cases were registered. It is caused by insufficient level of diagnostics in most of the regions, as a result, diseases pass under other diagnoses. Migratory birds ( 3 flyways of migratory birds pass through Ukraine) and local animals (crows, jackdaws, doves and other) may be the possible reservoirs of causative agent of WNF. Laboratory diagnostics need to be improved and more attention should be paid to testing of samples of blood serum from patients with suspected WNF.

\section{Keywords}

fever; enzootic territories; surveillance; mosquitoes; laboratory testing

\section{Acknowledgments}

Authors express their sincere gratitude for diagnostic kits to Dr. P. Emmerich, German Reference Center for Imported Parasitic and Viral Infections, Bernhard-Nocht Institute, Department of Virology.

\section{References}

[1] Rusev I.T., Zakusilo V.M., Vinnuk V.D. Bloodsucking mosquitoes of urbanized biocenosis and their role are in circulation of viruses of West Nile fever. Series are "Biology, chemistry". issue 24 (63). 2011. No. 2. p. 240-248.

[2] Lozinskyi I.M., Beletska G.V., Drul O.S., Fedoruck V.I., Kozlovskyi M.M., Rogochiy E.G., Sholomey M.V., Ben I.I., Shulgan A.M./ Epidemic situation of Western Nile fever in Ukraine. Magazine of infectology, issue 6, No. 2, 2014 Appendix 66-65.

[3] Official data of state statistic form of the Ministry of Health.

[4] Data of the State Institution Ukrainian center for Diseases Control and Monitoring of the Ministry of Health of Ukraine.

*Iryna Demchyshyna

E-mail: irad@i.ua 